\title{
A case study to determine the efficacy of ozonation in purification processes
}

\author{
S Morrison*, A Venter and S Barnard
}

School of Environmental Sciences and Development: Botany, North-West University, Potchefstroom 2520, South Africa

\begin{abstract}
The aim of this study was to determine the efficacy of ozone in water purification processes at the Midvaal Water Company, which uses the hypertrophic Middle Vaal River for source water. It was found that pre- and intermediate ozonation had no significant effect on pH, conductivity, dissolved organic carbon (DOC) and total organic carbon (TOC). Chlorophyll-a, total chlorophyll, spectral absorbance coefficient (SAC 254) and total algal cells were not influenced by pre-ozonation (as desired) but were greatly reduced after intermediate ozonation. The dissolved air flotation step which occurs after preozonation and prior to intermediate ozonation contributed to an average total chlorophyll removal of $74 \%$. The effect of ozonation on the removal of manganese, iron and aluminium could not be determined during this study since these elements were present in relatively low concentrations in the source water. Intermediate ozonation had variable effects on the removal of Cyanophyceae, Dinophyceae, Euglenophyceae and Chlorophyceae, but Chrysophyceae, Bacillariophyceae and Cryptophyceae were greatly reduced after this stage.
\end{abstract}

Keywords: water treatment, pre-ozonation, intermediate ozonation, SAC254, chlorophyll, algal cells

\section{Introduction}

Water is a scarce resource in South Africa and this situation may very well intensify over time, forcing purification companies to utilise every available water source, even a river, reservoir or wetland with water that looks like pea soup, or one clogged from bank to bank with aquatic plants (Davies and Day, 1998). However, due to the efficiency of water treatment processes, water for potable supply need not be of the highest quality (Mason, 1991); if a water source of better quality is not available, advanced treatment methods have to be implemented and developed. Potable water with tastes and odours can often be linked to a polluted or eutrophic natural resource and conventional water treatment methods may not effectively remove it. Therefore, it may be necessary to use more advanced water treatment processes in order to produce potable water of an acceptable quality (Pryor and Freeze, 2000).

Midvaal Water Company (Fig. 1) is situated on the banks of the Middle Vaal River $\left(26^{\circ} 48^{\prime} 1.4^{\prime \prime}\right.$ East and $26^{\circ} 56^{\prime} 4.5^{\prime \prime}$ South) in South Africa and abstracts between 95 and $180 \mathrm{M \ell}$ of water from the Vaal River per day. It has a capacity to treat $320 \mathrm{M} \ell$ of water daily. The Middle Vaal Water Management Area is mostly rural, where agriculture, mine de-watering, and the subsequent discharge into the river system, impact on the water quality (Anon, 2008). Tributaries in the catchment of the Vaal River also contribute to the deteriorating water quality of

\footnotetext{
* To whom all correspondence should be addressed.

용 +27 18299 2517; fax: +27 18299 2370; e-mail:10066551@nwu.ac.za

Received 28 June 2010; accepted in revised form 14 December 2011.
}

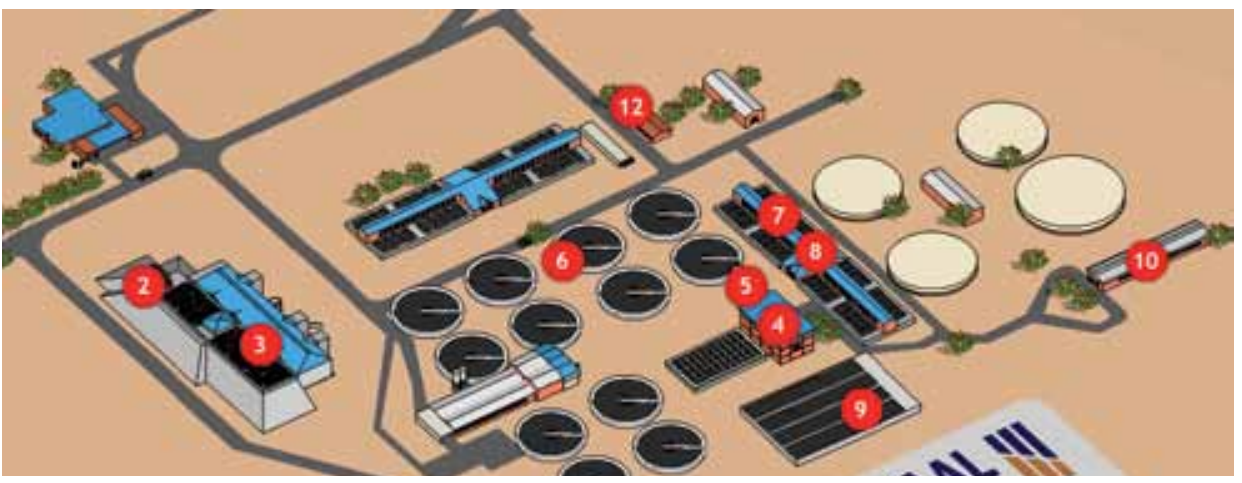

Figure 1

Schematic diagram of the different water treatment processes at Midvaal Water Company (midvaalwater.co.za)

$1=$ Water abstraction (not shown on diagram)

2 = Pre-ozonation and flocculation channels

$3=$ Dissolved air flotation

$4=$ Intermediate ozonation

$5=$ Control room

$6=$ Sedimentation

7 = Filtration

$8=$ Disinfection with chlorine gas

$9=$ Water recovery

$10=$ Storage and distribution

11 = Office (not shown on diagram)

$12=$ Laboratory

the Middle Vaal system (Anon., 2008) by introducing various pollutants into the system at times.

The production of drinking water from natural water necessitates the removal of numerous compounds present, mainly inorganic species, humic substances and pollutants (Camel and Bermond, 1998). Ozone, a potent germicide, is also used as an oxidising agent for the destruction of organic compounds producing taste and odours in drinking water, for the destruction of organic colouring matter and for the oxidation of reduced iron or manganese salts to insoluble oxides (Eaton et al., 1995). 
Due to its high oxidation potential ozone has been widely applied to water treatment. Midvaal Water Company has two U-tube reactors for intermediate ozonation (Fig. 1, No. 4) and also has a radial diffuser in the pre-ozonation reactor (Fig. 1. No. 2) in order to transfer the ozone gas into the source water. Since 1985 Midvaal Water Company has used pre-ozone in its treatment processes to remove high concentrations of manganese and iron (Anon., 2006) from the source water. The quality of the source water has changed over time and lower concentrations of manganese and iron are now present, but the source water has became more saline, with an increase in organic matter and algae. Therefore, a dissolved air flotation (DAF) plant was commissioned in 1998 (Fig. 1. No. 3), to remove content such as algae and organic matter that settle less readily (Anon., 2006). The initial pre-ozonation step became an intermediate step and in 2007 the existing ozonation plant was upgraded with the construction of a new pre-ozone reactor. The effect of DAF and ozonation on the turbidity and total chlorophyll of the final water can be seen in Figs. 2 and 3.

A pressure swing adsorption (PSA) system was also installed to produce oxygen for the ozone generators. Pressure swing adsorption is a process whereby a special molecular sieve is used under pressure to selectively remove nitrogen, carbon dioxide, water vapour, and hydrocarbons from air, producing an oxygen-rich $\left(80-95 \% \mathrm{O}_{2}\right)$ feed gas (USEPA, 1999). The aim of the pre-ozonation step is to inactivate the algae whilst keeping them intact, resulting in a more effective dissolved air flotation step.

The aim of this study was to determine the efficacy of ozonation in the water purification processes at Midvaal Water Company.

\section{Materials and methods}

Water samples were collected weekly for a 1-year period (October 2007 to September 2008), from the source water and after the water had been treated with an average of $2.4 \mathrm{mg} \cdot \ell^{-1}$ ozone for $4 \mathrm{~min}$ (intermediate ozonation). The pre-ozonation step was implemented only during the latter part of the study and water samples were collected weekly for the last 4 months of the study after the source water had been pre-ozonated with $1.3 \mathrm{mg} \cdot \ell^{-1}$ ozone for $2 \mathrm{~min}$.

Standard methods, some of which were accredited by the South African National Accreditation System (SANAS), were used to determine the $\mathrm{pH}$, conductivity; turbidity (NTU); chlorophyll- $a$; total chlorophyll (chlorophyll- $a$ and phaeophytin-a); dissolved organic carbon (DOC); total organic carbon (TOC); manganese (Mn), iron ( $\mathrm{Fe}$ ) and aluminium (Al), as well as Spectral Absorbance Coefficient (SAC 254) at Midvaal Water Company Scientific Services. Methylisoborneol (MIB) and geosmin analyses were done at Rand Water using the Purge and Trap system coupled to GC-MS.

Phytoplankton identification and enumeration were done according to the sedimentation technique using gravity as described by Swanepoel et al. (2008).

Due to the financial implications it was not expedient for the company to obtain multiple replications of a specific variable at each time interval for this case study. In some instances, problems with the infrastructure resulted in missing values at certain time intervals. Due to this fact, and the time-dependent nature of the data, statistical inference and other analyses such as principle component analyses were not an option. Therefore, effect sizes (Ellis and Steyn, 2003), instead of the usual $p$-values, were used to determine the importance of a specific

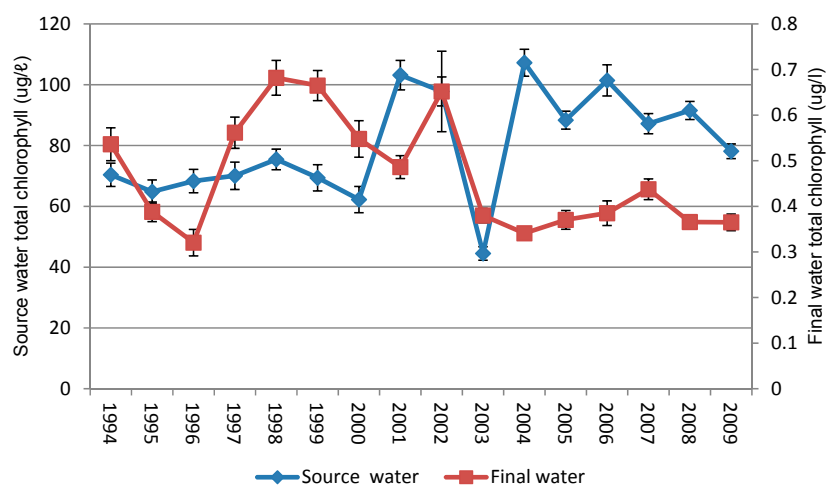

Figure 2

The average annual total chlorophyll $\left(\mu g \ell^{-1}\right)$ of the source and final water from 1994 to 2009

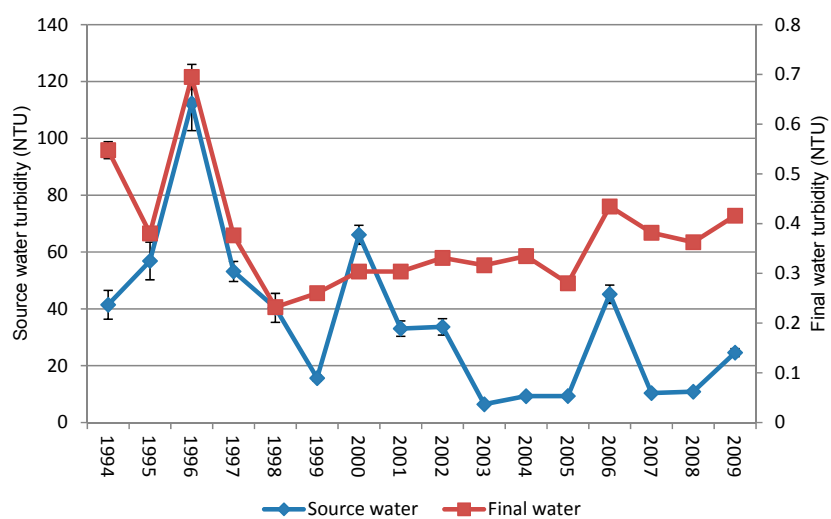

Figure 3

The average annual turbidity (NTU) of the source and final water from 1994 to 2009

measured variable. The effect size is independent of the sample size and is a measure of practical significance. Practical significance can be understood as a large enough difference to have an effect in practice (Ellis and Steyn, 2003).

\section{Results and discussion}

The ecological state of the source water (Table 1) compared favourably with trends identified in other studies, such as those of Pieterse and Janse van Vuuren (1997), Kruskopf (2002) and Carrim (2006), and no shift in environmental variables over time was detected. The target water quality objectives for the Middle Vaal catchment (DWAF, 2006) indicated that the concentrations of variables such as iron, manganese, nitrate and nitrite, orthophosphate, chloride, sodium, sulphate, faecal coliform bacteria, magnesium, aluminium, ammonia and fluoride were either ideal or acceptable, except for $\mathrm{pH}$ and conductivity which were unacceptable and tolerable, respectively. The high $\mathrm{pH}$ was ascribed to the excessive algal productivity associated with hypertrophic water systems and the high conductivity was a result of the limited rainfall (average of $58.25 \mathrm{~mm}$ for the study period) in this region together with increased salinisation of the system. During the study period, Chlorophyceae and Bacillariophyceae were the dominant algal classes in the source water and included genera such as Desmodesmus, Scenedesmus, Pediastrum, Monoraphidium, Aulacoseira, Cyclotella and Melosira. 


\begin{tabular}{|l|c|}
\hline \multicolumn{2}{|c|}{$\begin{array}{c}\text { Table 1 } \\
\text { The ecological state of the source water of } \\
\text { Midvaal Water Company }\end{array}$} \\
\hline Variable & $\begin{array}{c}\text { Average for } \\
\text { study period } \\
\text { (October 2007 } \\
\text { - September } \\
\text { 2008) }\end{array}$ \\
\hline $\mathrm{pH}$ & 8.64 \\
\hline Conductivity $\left(\mathrm{mS} \cdot \mathrm{m}^{-1}\right)$ & 76 \\
\hline Turbidity $(\mathrm{NTU})$ & 12 \\
\hline Chlorophyll- $a\left(\mu \mathrm{g} \cdot \ell^{-1}\right)$ & 64.6 \\
\hline Total chlorophyll $\left(\mu \mathrm{g} \cdot \ell^{-1}\right)$ & 105 \\
\hline TOC $\left(\mathrm{mg} \cdot \ell^{-1}\right)$ & 8.2 \\
\hline DOC $\left(\mathrm{mg} \cdot \ell^{-1}\right)$ & 6.2 \\
\hline Mn $\left(\mathrm{mg} \cdot \ell^{-1}\right)$ & 0.05 \\
\hline Fe $\left(\mathrm{mg} \cdot \ell^{-1}\right)$ & 0.02 \\
\hline Al $\left(\mathrm{mg} \cdot \ell^{-1}\right)$ & 0.03 \\
\hline SAC $254\left(\mathrm{~m}^{-1}\right)$ & 16.55 \\
\hline Cyanophyceae $\left(\mathrm{cells} \cdot \mathrm{m} \ell^{-1}\right)$ & 1751 \\
\hline Chrysophyceae $\left(\mathrm{cells} \cdot \mathrm{m} \ell^{-1}\right)$ & 5 \\
\hline Bacillariophyceae $\left(\mathrm{cells} \cdot \mathrm{m} \ell^{-1}\right)$ & 3663 \\
\hline Cryptophyceae $\left(\mathrm{cells} \cdot \mathrm{m} \ell^{-1}\right)$ & 16 \\
\hline Dinophyceae $\left(\mathrm{cells} \cdot \mathrm{m} \ell^{-1}\right)$ & 3 \\
\hline Euglenophyceae $\left(\mathrm{cells} \cdot \mathrm{m} \ell^{-1}\right)$ & 37 \\
\hline Chlorophyceae $\left(\mathrm{cells} \cdot \mathrm{m} \ell^{-1}\right)$ & 4907 \\
\hline Total algal cells $\left(\mathrm{cells} \cdot \mathrm{m} \ell^{-1}\right)$ & 10382 \\
\hline
\end{tabular}

Table 2 gives a summary of the influence of pre- and intermediate ozonation on the different variables measured during the study period. Table 3 gives the average percentage removal of a variable from the water after intermediate ozonation.

The overall influence of intermediate ozonation on $\mathrm{pH}$ and conductivity was insignificant. Mamba et al. (2009) monitored the natural organic matter and disinfection byproducts at different stages in Midvaal treatment plant and found that the $\mathrm{pH}$ increased from 8.85 (source water) to 8.92 after ozonation and that the conductivity also increased from $665 \mu \mathrm{S}$ (source water) to $735 \mu \mathrm{S}$. This increase can be associated with the addition of coagulants like ferric chloride and aluminium sulphate during coagulation as well as chlorine during chlorination (Mamba et al., 2009). This study also found a slight increase in the average $\mathrm{pH}$ from 8.63 (source water) to 8.74 after ozonation as well as in the conductivity, which increased from $87 \mathrm{mS} \cdot \mathrm{m}^{-1}$ (source water) to $88 \mathrm{mS} \cdot \mathrm{m}^{-1}$ after ozonation.

An extremely high turbidity of 48 NTU was measured in February 2008, which can be attributed to work done on the infrastructure of the plant, a testing error, environmental conditions upstream or sudden rainfall. However, intermediate ozonation had a considerable influence on turbidity, with an average removal of $43 \%$. Mamba et al. (2009) also observed a decrease in turbidity, from $0.36 \mathrm{NTU}$ in the source water to 0.12 NTU after ozonation.

Intermediate ozonation had variable influences on DOC and TOC (Table 3). Mamba et al. (2009) found a reduction in the TOC from $14.53 \mathrm{mg} \cdot \ell^{-1}$ in the source water to $10.40 \mathrm{mg} \cdot \ell^{-1}$ after ozonation at Midvaal Water Company. However, Pryor et al. (2002) also found that ozone had little or no effect on the TOC of water at the Wiggins Treatment Plant in Durban. These authors found that at high TOC concentrations a decrease of up to $25 \%$ was possible at applied ozone doses of 0.3 to $0.5 \mathrm{mg}$ $\mathrm{O}_{3} \cdot \mathrm{mg}^{-1} \mathrm{DOC}$, generally 2 to $4 \mathrm{mg} \cdot \ell^{-1} \mathrm{O}_{3}$ (Pryor et al., 2002).
The influence of pre- and intermediate ozonation on parameters measured during the study

\begin{tabular}{|l|l|l|}
\hline & Pre-ozonation & Intermediate ozonation \\
\hline & Variable influence & Variable influence \\
\hline & Variable influence & Variable influence \\
\hline & Variable influence & Variable influence \\
\hline & Variable influence & Decrease \\
\hline Variable influence & Variable influence \\
\hline & Variable influence & Variable influence \\
\hline & & Increase \\
\hline & Variable influence & Variable influence \\
\hline & Variable influence & Decrease \\
\hline & & Decrease \\
\hline & Variable influence & Variable influence \\
\hline & Variable influence & Variable influence \\
\hline & Variable influence & Decrease \\
\hline
\end{tabular}

\begin{tabular}{|l|c|}
\hline \multicolumn{2}{|c|}{$\begin{array}{c}\text { Table 3 } \\
\text { The average percentage removal of } \\
\text { variables after intermediate ozonation }\end{array}$} \\
\hline $\mathrm{pH}$ & $-1.3 \%$ \\
\hline Conductivity & $-3 \%$ \\
\hline Turbidity (NTU) & $43 \%$ \\
\hline Chlorophyll- $a$ & $72 \%$ \\
\hline Total chlorophyll & $74 \%$ \\
\hline TOC & $14 \%$ \\
\hline DOC & $6 \%$ \\
\hline Mn & $40 \%$ \\
\hline Fe & $50 \%$ \\
\hline Al & $33 \%$ \\
\hline SAC 254 & $37 \%$ \\
\hline MIB & $-47 \%$ \\
\hline Cyanophyceae & $61 \%$ \\
\hline Chrysophyceae & $100 \%$ \\
\hline Bacillariophyceae & $76 \%$ \\
\hline Cryptophyceae & $96 \%$ \\
\hline Dinophyceae & $33 \%$ \\
\hline Euglenophyceae & $76 \%$ \\
\hline Chlorophyceae & $46 \%$ \\
\hline Total algal cells & $59 \%$ \\
\hline
\end{tabular}

Song et al. (2010) found that $3 \mathrm{mg} \cdot \ell^{-1} \mathrm{O}_{3}$ removed only $10 \%$ of the DOC in the Huangpu River water.

Iron, manganese and aluminium were present in such low concentrations in the source water during the study period that they were below the method detection limit, and the influence of intermediate ozonation on the removal of these elements had variable results (Table 3 ). The dosing of coagulants such as aluminium sulphate or ferric chloride at a secondary dosing point prior to intermediate ozonation may cause increases in iron and aluminium concentrations at times. A settling process follows after intermediate ozonation and the final water quality complied with Class I criteria (SANS 241: 2006 edition 6.1. However, Amirsardari et al. (1997) found that $1.2 \mathrm{mg} \cdot \ell^{-1} \mathrm{O}_{3}$ removed $97 \%$ manganese from the source 


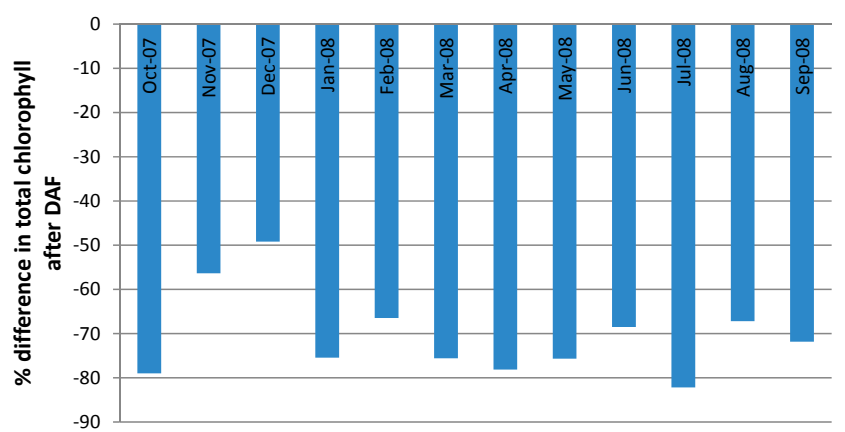

Figure 4

The average monthly influence of dissolved air flotation (DAF) on total chlorophyll of the source water

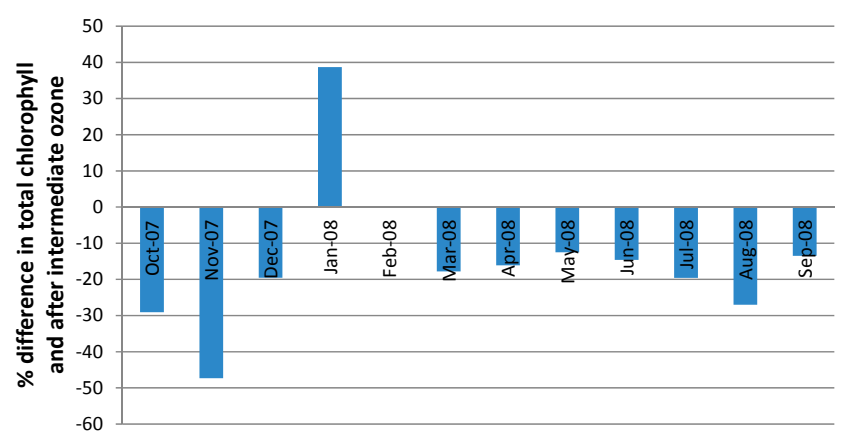

Figure 5

The average monthly influence on the total chlorophyll of the water after intermediate ozonation

water of a treatment plant of North Pine Dam near Brisbane, Australia.

Ozone proved to be effective in reducing UV absorbance $(254 \mathrm{~nm})$, as SAC 254 was reduced after intermediate ozonation for each month of the study period. The average removal of SAC 254 was $37 \%$ for the study period. The DAF process contributed to this since it had a major impact on the chlorophyll concentrations (Fig. 4) which are closely related to SAC 254.

Figure 4 indicates that the largest total chlorophyll removal was achieved with the DAF process prior to intermediate ozonation and Fig. 5 shows that the total chlorophyll concentration of the source water after it has been treated with ozone was constantly lower than the total chlorophyll concentration of the source water. In January 2008 the Cyanophyta (11 904 cells $\left.\cdot \ell^{-1}\right)$, Chlorophyta $\left(7714\right.$ cells $\left.\cdot \ell^{-1}\right)$ and Bacillariophyta (6 577 cells $\cdot \mathrm{m}^{-1}$ ) concentrations were very high in the source water. However, the highest total chlorophyll concentration for the source water $\left(220 \mu \mathrm{g} \cdot \ell^{-1}\right)$ was measured in February 2008 and also after ozonation $\left(98 \mu \mathrm{g} \cdot \ell^{-1}\right)$.

The total algal cell count was constantly reduced after the ozonation process (Fig. 6), with the average algal cells decreasing from 10382 cells $\cdot \mathrm{m}^{-1}$ in the source water to 4255 cells $\cdot \ell^{-1}$ after intermediate ozonation, a removal of $59 \%$. The Bacillariophyceae and Chlorophyceae cells which comprised the biggest part of the algal composition of the source water were reduced after intermediate ozonation, except in May 2008. During this time the Chlorophyceae cells increased after intermediate ozonation due to an excessive increase of the genera Desmodesmus and Actinastrum. The Chrysophyceae, Cryptophyceae, Dinophyceae and Euglenophyceae were successfully removed by ozonation.

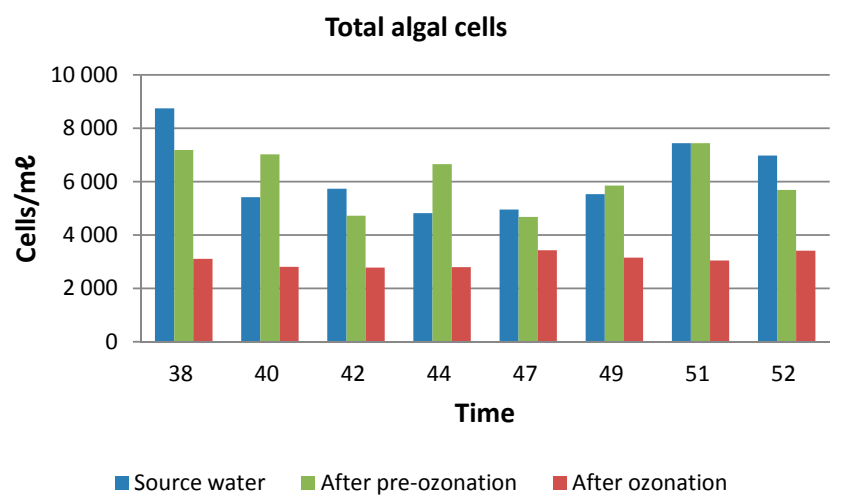

Figure 6

The total algal cells. $m \ell^{-1}$ of source water, after pre-ozonation and intermediate ozonation, counted twice a month for the sampling period, June 2008 (Week 38 and 40) to September 2008 (Week 51 and 52)

The Cyanophyceae was the only algal class from which cells were identified in samples after intermediate ozonation, even though they were not detected in the specific source water samples. During January 2008, Cyanophyceae, especially Oscillatoria species, dominated, causing consumer complaints about unpleasant taste and odours in the drinking water. At the time the total chlorophyll concentration in the source water was $182 \mu \mathrm{g} \cdot \ell^{-1}$ and the MIB concentration increased from $160 \mu \mathrm{g} \cdot \ell^{-1}$ in the source water to $333 \mu \mathrm{g} \cdot \ell^{-1}$ after ozonation, even though the Cyanophyceae which dominated in the source water at the time were greatly reduced after intermediate ozonation. These unexpected results can be the result of a waste stream with extremely high algal counts that enters the water purification process at the DAF stage for recycling purposes. Conflicting results have been reported in the removal of taste and odours by ozonation (Geldenhuys et al., 2000). Pryor and Freeze (2000) achieved removal of geosmin and (MIB) in excess of $70 \%$ at ozone to DOC ratios of between 0.5 and 1.5 , which may explain why MIB was not removed at Midvaal during the study period as the ozone to DOC ratio was 2.6.

Visser (1996) concluded that different algal species or morphological groups required different treatment conditions to be successfully removed during water purification; thus, the filtration processes at Midvaal Water Company are as important as any other stage in the water purification process for removing the remaining algal cells. The study at Midvaal demonstrated the crucial role of the DAF process in the overall success of the plant, by removing a great number of algal cells intact.

Tables 4 and 5 give the effect sizes of the different parameters and algal classes, respectively, confirming that ozone had the biggest influence on SAC 254 and was effective in removing the Bacillariophyceae.

Pre-oxidation leads to the elimination of mineral compounds, colour, turbidity, suspended solids, tastes and odours and, in addition, this step partly degrades natural organic matter and inactivates micro-organisms; finally, this treatment generally enhances the coagulation-flocculation-decantation step (Camel and Bermond, 1998). Pre-ozonation did not have an effect on the chlorophyll concentrations of the source water as was both desired and expected. The influence of pre-ozonation on the water purification process at Midvaal Water Company, including the DAF process, could not successfully be investigated during this study as the duration of the study period was insufficient. This aspect of the water purification process at 


\begin{tabular}{|c|c|c|}
\hline \multicolumn{3}{|c|}{$\begin{array}{c}\text { Table } 4 \\
\text { The effect of intermediate ozonation on variables in } \\
\text { the source water in order of importance (effect sizes) }\end{array}$} \\
\hline $\begin{array}{l}\text { Order of } \\
\text { importance }\end{array}$ & Variable & Effect size \\
\hline 1 & SAC 254 & 2.188 \\
\hline 2 & Chlorophyll- $a$ & 1.551 \\
\hline 3 & Total chlorophyll & 1.538 \\
\hline 4 & Total algal cells & 0.796 \\
\hline 5 & Turbidity (NTU) & 0.762 \\
\hline 6 & TOC & 0.553 \\
\hline 7 & $\mathrm{Mn}$ & 0.489 \\
\hline 8 & DOC & 0.350 \\
\hline 9 & $\mathrm{pH}$ & 0.314 \\
\hline 10 & $\mathrm{Fe}$ & 0.214 \\
\hline 11 & Conductivity & 0.188 \\
\hline 12 & $\mathrm{Al}$ & 0.181 \\
\hline
\end{tabular}

\begin{tabular}{|c|c|c|}
\hline \multicolumn{3}{|c|}{$\begin{array}{c}\text { Table } 5 \\
\text { The effect of intermediate ozonation on the different } \\
\text { algal classes in the source water in order of } \\
\text { importance (effect sizes) }\end{array}$} \\
\hline $\begin{array}{l}\text { Order of } \\
\text { importance }\end{array}$ & Variable & Effect size \\
\hline 1 & Bacillariophyceae & 1.216 \\
\hline 2 & Chlorophyceae & 0.870 \\
\hline 3 & Euglenophyceae & 0.558 \\
\hline 4 & Cryptophyceae & 0.525 \\
\hline 5 & Cyanophyceae & 0.229 \\
\hline 6 & Chrysophyceae & 0.204 \\
\hline 7 & Dinophyceae & 0.111 \\
\hline
\end{tabular}

Midvaal Water Company requires further study and investigation over a longer period, especially since other studies have indicated conflicting results about the effect of pre-ozonation on coagulation and flocculation (Pryor and Freeze, 2000).

A survey on ozone use in the South African water industry showed that ozone use locally is growing rapidly, especially as a pre-oxidant in the pre-treatment and intermediate stages of the water treatment process chain (Rajagopaul et al., 2008). However, there are conflicting reports on the influence of ozone on water quality and these must be examined before the decision is made to install an ozone plant as part of a treatment process (Carrim, 2006). The cost-effective operation of the ozonation process depends on 4 factors: ozone production, ozone dose, ozone contacting and ozone destruction (Rajagopaul et al., 2008). The effect of ozonation on coagulation and flocculation as well as the organic material need to be investigated thoroughly. The point of ozone application in the current water purification process should be determined as well as the optimum dosage, together with an accurate cost-benefit analysis of the ozonation process in order to ensure well-informed decision making. Utilities use ozone to achieve multiple water quality benefits, however, by-product formation (e.g., bromate) frequently controls process decisions such as location of ozonation system, $\mathrm{pH}$ depression, ammonia addition, ozone dose and hydrogen peroxide addition (Westerhoff et al., 2006). Process controllers should then be trained in the health and safety aspects of ozonation and also be provided with a complete operation manual. It is recommended that operations and maintenance personnel are adequately trained in the optimisation of the ozone plant and in troubleshooting ozone process problems (Rajagopaul et al., 2008).

\section{Conclusion}

The Middle Vaal River was determined to be hypertrophic, with Chlorophyceae and Bacillariophyceae as dominating algal classes. Intermediate ozonation either reduced or had a variable influence on the physical and chemical characteristics of the water as well as algal species composition, but, together with the dissolved air flotation, was shown to be a crucial step in the water purification process at Midvaal Water Company.

Pre-ozonation did not have an influence on the chlorophyll concentrations of the source water as was both desired and expected but the limited study period justifies further investigation into the effects of this treatment step on the water purification process at Midvaal Water Company. It should be continuously optimised according to the quality of the source water to ensure an optimised DAF process. During Oscillatoria blooms the ozone dosage should be adjusted in order to reduce or eliminate taste and odours in the final drinking water. Granular activated carbon (GAC) may also be used additionally to remove hydrophobic micro-pollutants such as MIB that cannot be oxidised by ozone (Sánchez-Polo et al., 2006).

Hunter (2003) concluded in his study that, because of climate change, there may be an increase in the number of cyanobacterial blooms, due to a combination of increased nutrient concentrations and water temperature. Increased cyanobacterial blooms will make water treatment plants such as Midvaal Water Company even more reliant on their ozonation processes; however, since Rapala et al., (2002) found that ozonation and chlorination had little effect on the endotoxin concentrations associated with cyanobacteria, this creates the need for innovative thinking and investigation in the never-ending pursuit of the goal of providing the people of South Africa with safe and healthy drinking water.

\section{References}

AMIRSARDARI Y, YU Q and WILLIAMS P (1997) Effects of ozonation and coagulation on turbidity and TOC removal by simulated direct filtration for potable water treatment. Environ. Technol. 18 (11) $1143-1150$

ANON. (2006) Ozonation at Midvaal Water Company. Water Sanit. 1 (2) (September/October) 34.

ANON. (2008) Vaal River System under scrutiny. The Water Wheel 7 (3) (May/June) 18.

CAMEL V and BERMOND A (1998) The use of ozone and associated oxidation processes in drinking water treatment. Water Res. 32 (11) 3208-3222.

CARRIM AH (2006) The effect of pre-ozonation on the physical characteristics of source water and natural organic matter (NOM) in source water from different South African water resources. M.Sc Dissertation, North-West University, Potchefstroom. 129 pp.

DAVIES BD and DAY J (1998) Vanishing Waters. University of Cape Town Press, Cape Town. 487 pp.

DWAF (DEPARTMENT OF WATER AFFAIRS AND FORESTRY, SOUTH AFRICA) (2006) Development of a Catchment Management Strategy for the Schoonspruit and Koekemoerspruit Catchments in the Middle Vaal Management Area. Phase II. Prepared by R Heath (unpublished document).

EATON AD, CLESCERI LS and GREENBERG AE (1995) Standard Methods for the Examination of Water and Wastewater ( $19^{\text {th }}$ edn.). American Public Health Association, Washington DC.

ELLIS SM and STEYN HS (2003) Practical significance (effect sizes) versus or in combination with statistical significance (p-values). Manage. Dyn. 12 (4) 51-53.

GELDENHUYS JC, GIARD E, HARMSE M, NEVELING K and POTGIETER M (2000) The use of ozonation with lime and activated sodium silicate in water treatment. WRC Report No. 
446/1/00. Water Research Commission, Pretoria. 63 pp.

HUNTER PR (2003) Climate change and waterborne and vector-borne disease. J. Appl. Microbiol. 94 37S-46S.

KRUSKOPF MM (2002) Phosphatase activities of riverine phytoplankton in the Vaal River (South Africa): physiological responses of nuisance species to different nutrient regimes. $\mathrm{Ph}$. D. Theseis. North-West University, Potchefstroom. 255 pp.

MAMBA BB, KRAUSE RW, MATSEBULA B and HAARHOFF J (2009) Monitoring natural organic matter and disinfection byproducts at different stages in two South African water treatment plants. Water SA 35 (1) 121-127.

MASON CF (1991) Biology of Freshwater Pollution (2 ${ }^{\text {nd }}$ edn.). Longman Scientific and Technical, Harlow. $351 \mathrm{pp}$.

PIETERSE AJH and JANSE VAN VUUREN S (1997) An investigation into phytoplankton blooms in the Vaal River and the environmental variables responsible for their development and decline. WRC Report No. 359/1/97. Water Research Commission, Pretoria. $245 \mathrm{pp}$.

PRYOR MJ and FREEZE SD (2000) The treatment of eutrophic water using pre- and intermediate ozonation, peroxone and pica carbon. WRC Report No. 694/1/00. Water Research Commission, Pretoria. $136 \mathrm{pp}$.

PRYOR MJ, NAIDOO PS, BAHRS P and FREESE SD (2002) Ozone experience at Umgeni Water. Presented at the biennial conference of the Water Institute of Southern Africa. URL: www.waterinformation.co.za (Accessed April 2011).

RAJAGOPAUL R, MBONGWA NW and NADAN C (2008) Guidelines for the selection and effective use of ozone in water treatment. WRC Report No. 1596/01/08. Water Research Commission, Pretoria. $81 \mathrm{pp}$.
RAPALA J, LAHTI K, RASANEN LA, ESALA AL, NIEMELA SI and SIVONEN K (2002) Endotoxins associated with cyanobacteria and their removal during drinking water treatment. Water Res. 36 (10) 2627-2635.

SÁNCHEZ-POLO M, SALHI E, RIVERA-UTRILLA J and VON GUNTEN U (2006) Combination of ozone with activated carbon as an alternative to conventional advanced oxidation processes. Ozone: Sci. Eng. 28 237-245.

SONG Y, DONG B, GAO N and XIA S (2010) Huanpu River water treatment by microfiltration with ozone pre-treatment. Desalination 250 71-75.

SOUTH AFRICAN NATIONAL STANDARD (SANS) 241-1 (2006) Drinking Water Edition 6.1. www. Capetown.gov.za (Accessed 11 January 2012)

SWANEPOEL A, DU PREEZ H, SCHOEMAN C, JANSE VAN VUUREN S and SUNDRAM A (2008) Condensed laboratory methods for monitoring phytoplankton, including cyanobacteria, in South African freshwaters. WRC Report No. TT 323/08. Water Research Commission, Pretoria. 108 pp.

USEPA GUIDANCE MANUAL (1999) Environmental Protection Agency Guidance Manual: Alternative Disinfectants and Oxidants. Chapter 3: Ozone. URL: www.epa.gov/safewater/mdbp/alternative disinfectants guidance.pdf (Accessed 27 July 2007).

VISSER R (1996) Algal species penetrating water purification processes in the Balkfontein purification plant. M.Sc. Dissertation, North-West University, Potchefstroom. 147 pp.

WESTERHOFF P, NALINAKUMARI B and PEI P (2006) Kinetics of MIB and geosmin oxidation during ozonation. Ozone: Sci. Eng 28 277-286. 